\title{
SELF EMPOWERMENT DAN KUALITAS HIDUP LANSIA KOTA SURABAYA
}

\author{
Chindy Maria Orizani ${ }^{1}$, Gea Sanimustofies ${ }^{2}$ \\ Prodi DIII Keperawatan STIKes Adi Husada Surabaya, Jawa Timur, Indonesia \\ chindyorizani@gmail.com
}

\begin{abstract}
Abstrak
Kemampuan seseorang atau pemberdayaan diri lansia dalam memenuhi kebutuhan, memecahkan masalah, memanfaatkan sumber daya yang ada untuk kehidupannya. Self empowerment yang dialami lansia menyebabkan perubahan kualitas hidup. Tujuan penelitian untuk mengidentifikasi hubungan self empowerment dengan kualitas hidup lansia di Wilayah Kelurahan TKK RW 2, Kota Surabaya. Penelitian ini menggunakan pendekatan cross sectional dan metode korelasional. Variabel independen self empowerment dan variabel dependen kualitas hidup. Populasi penelitian ini adalah semua lansia yang berada di Wilayah Kelurahan TKK RW 2, Kota Surabaya sebanyak 34 lansia. Pengambilan sampel menggunakan teknik total sampling yaitu 34 responden. Alat ukur yang digunakan adalah kuesioner WHOQOL dan kuesioner self empowerment. Hasil penelitian dilakukan uji statistik menggunakan chi-square dan menunjukkan terdapat hubungan yang bermakna $(p=0,000)$, dan memiliki hubungan yang kuat dengan nilai $(\mathrm{r}=1,000)$ antara self empowerment dengan kualitas hidup lansia di Wilayah Kelurahan TKK RW 2, Kota Surabaya. Permasalahan yang timbul pada lansia antara lain ketidakmampuan mengakses layanan kesehatan, tidak ada jaminan hari tua dan kurang dukungan sosial. Akibat permasalahan tersebut, lansia merasa tidak berdaya dan tidak berguna (lack of self empowerment) dalam kehidupan sehari-hari.
\end{abstract}

Kata Kunci : Self Empowerment, Kualitas Hidup, Lansia

\begin{abstract}
An individual's ability or self-empowerment of the elderly in meeting needs, solving problems, utilizing existing resources for their lives. Self empowerment experienced by the elderly causes changes in the quality of life. The purpose of the study was to identify the relationship between self-empowerment and the quality of life of the elderly in RW 02, TKK sub-district/district, Surabaya City. This research uses cross sectional approach and correlational method. The independent variable is self-empowerment and the dependent variable is quality of life. The population in this study were all elderly who were in the RW 02 area, TKK sub-district/district, Surabaya as many as 34 elderly. Sampling used a total sampling technique, namely 34 respondents. The measuring instrument used is the WHOQOL questionnaire and the self-empowerment questionnaire. The results of the study were statistical tests using chi-square and showed that there was a significant relationship $(p=0,000)$ and was a strong relationship $(r=1,000)$ between self empowerment and the quality of life of the elderly in $R W 02$, TKK sub-district/district, Surabaya City. Problems that arise in the elderly include the inability to access health services, no old-age insurance and lack of social support. As a result of these problems, the elderly feel powerless and useless (lack of self-empowerment) in everyday life.
\end{abstract}

Keywords: Self Empowerment, Quality of Life, Elderly

\section{PENDAHULUAN}

Pertambahan usia akan mengakibatkan degenerasi pada fisik maupun psikis. Akibat dari pertambahan usia pada lansia akan mengalami banyak perubahan karena menua yang akan menuntut lansia untuk dapat menyesuaikan diri. Lansia akan mengalami stres, kecemasan sampai tahap depresi jika lansia tersebut tidak mampu beradaptasi dan

Corresponding author:

Chindy Maria Orizani

chindyorizani@gmail.com 
menyesuaikan diri terhadap perubahan (Gallo, 2008). Pertambahan usia juga dapat mengakibatkan penurunan kesehatan (perubahan fisik), tidak bekerja, dan dinilai sebagai individu yang tidak mampu/berdaya dalam melakukan aktivitas sehari-hari. Menurut (Nainggolan, 2014) dampak dari pertumbuhan usia akan menyebabkan gangguan penurunan pemberdayaan diri (Self Empowerment) pada lansia.

Self empowerment menyesuaikan tujuan hidup lansia dan selaras dengan kondisi dirinya. Penurunan self empowerment pada lansia didasarkan pada adanya ketidakinginan dari lansia sendiri dan penurunan kondisi lansia, sedangkan kesediaan dan keinginan untuk berdaya dapat menjadi dampak positif dalam mempertahankan kualitas hidup lanjut usia sehingga menurunnya self empowerment dapat mempengaruhi kualitas hidup lansia (Nainggolan, 2014).

Mempertahankan harapan dan kualitas hidup pada lansia merupakan hal yang penting. Domain kualitas hidup terdiri dari kesehatan fisik, kesehatan psikologi, hubungan sosial, dan aspek lingkungan. Jika salah satu dari domain tersebut tidak terpenuhi maka masalah bisa timbul pada lansia dan mengakibatkan penurunan kualitas hidup (Rohmah et al., 2012).

Tahun 2020, jumlah lansia sudah menyamai jumlah balita. $11 \%$ dari 6,9 milyar penduduk dunia adalah lansia. Data World Health Statistic 2013, Indonesia menduduki urutan keempat dengan 242 juta penduduk (WHO, 2013). Badan Pusat Statistik (2013) proposi penduduk Tahun 2018 usia 60 tahun ke atas sebesar 24.754 .500 jiwa $(9,34 \%)$ dari total populasi. Survei permulaan dilakukan peneliti terhadap 10 lansia di Wilayah Kelurahan TKK RW 2, Kota Surabaya, didapatkan 8 lansia memiliki kualitas hidup dan Self Empowerment yang kurang serta 2 lansia memiliki kualitas hidup dan Self Empowerment yang baik.

Self empoworment atau "pemberdayaan diri" adalah kemampuan gambaran konsep pemberdayaan diri atau kemampuan individu untuk memenuhi kebutuhannya sendiri, pemecahan masalah secara pribadi, dan mengakomodasi sumber daya yang diperlukan untuk melangsungkan kehidupan mereka (Rahayu, 2013). Faktor yang mempengaruhi self empowerment, yaitu: (1) ketersediaan informasi menjadi faktor penting yang memungkinkan untuk pengambilan keputusan, (2) perilaku yang memungkinkan untuk mengembangkan kemampuan dalam pemecahan masalah, meningkatkan keyakinan diri dan mendukung aplikasi pengetahuan dalam kehidupan, (3) tanggung jawab pribadi langsung terhadap perawatan diri pada penyakitnya. Faktor tersebut berdampak pada pemeliharaan kualitas hidup lansia yang dipengaruhi oleh: (1) jenis kelamin, (2) usia, (3) pendidikan mempengaruhi kualitas hidup secara subjektif, dan (4) pekerjaan, (5) status pernikahan, (6) hubungan sosial dengan orang lain, (7) kesehatan fisik (Salsabila, 2012). Dampak self empowerment yang rendah akan mengakibatkan kualitas hidup yang kurang akan mengakibatkan pengetahuan, keterampilan, dan sikap pada lansia juga berkurang (Rohanah \& Suyatini, 2018). Dampak dari rendahnya kualitas hidup lansia yaitu munculnya penyakit degeneratif, ketidaksejahteraan secara ekonomi dan sosial serta tidak produktif (Rohmah et al., 2012)

Untuk menangani lansia ini, diperlukan self empowerment yang baik dari diri lansia sebagai upaya meningkatkan seluruh aspek kemampuan meliputi fisik, psikis, pengetahuan dan keterampilan, spiritual, sosial, agar lansia tetap berdaya guna sesuai dengan kondisi dan kemampuannya. Kesadaran diri lansia diperlukan untuk tetap aktif melakukan aktivitas atas kemauan sendiri sehingga merasa berharga, dan berdampak positif dalam mempertahankan kualitas hidup (Nainggolan, 2014).

Tujuan studi ini untuk mengidentifikasi apakah ada hubungan self empowerment dengan kualitas hidup pada lansia.

\section{METODE PENELITIAN}

Desain penelitian menggunakan desain korelasional dengan pendekatan cross sectional. Populasi yang digunakan dalam penelitian ini adalah seluruh lansia di Wilayah Kelurahan TKK RW 2, Kota Surabaya berjumlah 34 lansia. Teknik sampling menggunakan total sampling yaitu jumlah sampel sama dengan populasi. Jumlah populasi sebanyak 34 lansia, sehingga total sampelnya 34 responden.

Variabel terdiri dari self empowerment dan kualitas hidup. Data diperoleh melalui kuesioner Self Empowerment dan WHO-QOL. 
Penelitian ini dilakukan pada 28 Maret 2021 - 17 April 2021 dan lokasi penelitian di Wilayah RW 02 Wilayah Wilayah Kelurahan TKK RW 2, Kota Surabaya.

Proses penelitian ini dilakukan setelah Peneliti mengajukan surat izin penelitian dari Sekolah Tinggi Ilmu Kesehatan Adi Husada kepada BaKesBangPol. Selanjutnya Peneliti meminta izin di Wilayah Wilayah Kelurahan TKK RW 2, Kota Surabaya. Peneliti menyiapkan alat ukur yang digunakan adalah kuesioner WHOQOL dan kuesioner self empowerment yang mengabdopsi dari (Fajriana, 2017) yang telah diuji kesahihan dan kehandalan. Peneliti kemudian melakukan pendekatan dengan responden dan memberikan penjelasan tentang tujuan dari peneliti. Peneliti memberikan lembar persetujuan menjadi responden (informed consent) selanjutnya peneliti memberi kuesioner. Selama pengisian kuisioner peneliti mendampingi responden, apabila dalam pengisian kuisioner mengalami kesulitan peneliti dapat menjelaskan dan membantu responden.

\section{HASIL}

\section{Analisa Univariat}

Tabel 1 Distribusi Frekuensi Karakteristik Responden

\begin{tabular}{lcc}
\hline \multicolumn{1}{c}{ Karakteristik } & Frekuensi & Presentase \\
\hline Usia & & \\
\hline $60-74$ tahun & 32 & 94,1 \\
$75-90$ tahun & 2 & 5,9 \\
$>90$ tahun & 0 & 0 \\
\hline Total & 34 & 100 \\
\hline Jenis & & \\
Kelamin & & \\
\hline Laki-laki & 4 & 11,8 \\
Perempuan & 30 & 88,2 \\
\hline Total & 34 & 100 \\
\hline Pendidikan & & \\
\hline SD & 29 & 85,3 \\
SMP & 3 & 8,8 \\
SMA/SMK & 2 & 5,9 \\
Pendidikan Tinggi & 0 & 0 \\
\hline Total & 34 & 100 \\
\hline Pekerjaan & & \\
\hline Pengawai Negeri & 0 & 0 \\
Pegawai Swasta & 0 & 0 \\
Wiraswasta & 2 & 5,8 \\
Ibu Rumah Tangga & 13 & 38,2 \\
tidak bekerja & 19 & 56,0 \\
\hline Total & 34 & 100 \\
\hline & &
\end{tabular}

Berdasarkan Tabel 1 menunjukkan bahwa karakteristik responden mayoritas adalah usia 60-74 tahun sebanyak 32 orang $(94,1 \%)$, sebagian besar berjenis kelamin perempuan sebanyak 30 orang $(88,2 \%)$, hampir sebgian memiliki pendidikan terakhir SD sebanyak 29 orang $(85,3 \%)$, dan sebagian tidak bekerja sebanyak 19 orang $(56,0 \%)$.

\section{Tabel 2 Karakteristik Responden Berdasarkan Self Empowerment}

Self Empowerment Frekuensi Presentase

\begin{tabular}{lcc} 
Baik & 2 & 5,9 \\
\hline Kurang & 32 & 94,1 \\
\hline Total & 34 & 100 \\
\hline
\end{tabular}

Berdasarkan Tabel 2 menunjukan bahwa mayoritas responden mempunyai self empowerment yang kategori kurang yaitu sebanyak 32 orang $(94,1 \%)$.

Tabel 3 Karakteristik Responden Berdasarkan Kualitas Hidup

\begin{tabular}{lll}
\hline Kualitas Hidup & Frekuensi & Presentase \\
\hline Baik & 2 & 5,9 \\
\hline Kurang & 32 & 94,1 \\
\hline Total & 34 & 100 \\
\hline
\end{tabular}

Tabel 3 menunjukan bahwa mayoritas responden mempunyai kualitas hidup yang kategori kurang yaitu sebanyak 32 orang $(94,1$ $\%)$.

\section{Analisis Bivariat}

Tabel 4 Hubungan Self Empowerment dengan Kualitas Hidup

\begin{tabular}{|c|c|c|c|c|c|c|}
\hline \multirow{3}{*}{$\begin{array}{c}\text { Self } \\
\text { Empowerment }\end{array}$} & \multicolumn{6}{|c|}{ Kualitas Hidup } \\
\hline & \multicolumn{2}{|c|}{ Baik } & \multicolumn{2}{|c|}{ Kurang } & \multicolumn{2}{|c|}{ Total } \\
\hline & $\mathbf{F}$ & $\%$ & $\mathbf{F}$ & $\%$ & $\mathbf{F}$ & $\%$ \\
\hline Baik & 2 & 100 & 0 & 0 & 2 & 5,9 \\
\hline Kurang & 0 & 0 & 32 & 100 & 32 & 94,1 \\
\hline Total & 2 & 100 & 32 & 100 & 34 & 100 \\
\hline \multicolumn{7}{|c|}{$\begin{array}{c}\text { Uji statistik chi-squere } \\
p \text { value }=0,000, \mathrm{r}=1,000\end{array}$} \\
\hline
\end{tabular}

Tabel 4 menunjukan bahwa sebagian besar responden dengan self empowerment memiliki kualitas hidup yang kurang sebesar 32 $(94,1 \%)$ lansia. Hasil uji statistik chi-squere pada variabel yaitu $\mathrm{p}=0,000$ artinya ada hubungan yang bermakna antara self empowerment dan kualitas hidup lansia dan 
nilai $\mathrm{r}=1,000$ menunjukkan adanya hubungan kuat antar variabel.

\section{PEMBAHASAN}

\section{Mengidentifikasi Self Empowerment pada Lansia}

Berdasarkan hasil penelitian pada tabel 2 didapatkan sebagian besar responden memiliki self empowerment kurang sebanyak 32 responden $(94,1 \%)$. Self empoworment atau "pemberdayaan diri" adalah kemampuan gambaran konsep pemberdayaan diri atau kemampuan individu untuk memenuhi kebutuhannya sendiri, pemecahan masalah secara pribadi, dan mengakomodasi sumber daya yang diperlukan untuk melangsungkan kehidupan mereka (Rahayu, 2013). Adanya self empowerment bertujuan untuk membentuk individu yang mandiri dalam hal berfikir, bertindak, serta mengendalikan perilaku demi mencapai pemecahan masalah yang dihadapi dengan kemampuan yang dimilikinya (Rahayu, 2013).

Hasil penelitian menunjukkan sebagian besar lansia berusia 60-74 tahun sebanyak 32 lansia $(94,1 \%)$ yang berada di Wilayah Wilayah Kelurahan TKK RW 2, Kota Surabaya, mengalami self empowerment yang kurang. Hal ini sejalan dengan teori yang menunjukkan bahwa lansia dengan bertambahnya usia maka terjadi kelemahan baik secara fisik maupun psikis. Kemunduran fisik lansia mengakibatkan keterbatasan dalam memenuhi kebutuhan sehari-hari dan mengakses layanan kesehatan. Berkurangnya kekuatan fisik sehingga berkurangnya pendapatan. Pemerintah memberikan perhatian khusus terhadap lansia melalui program layanan lansia baik di puskesmas maupun tingkat layanan yang lebih tinggi. Meskipun demikian, kesejahteraan lansia masih belum terpenuhi secara memadai. Kenyataannya jumlah lansia kurang mampu jauh lebih banyak dari lansia mapan. Namun lansia tetap memiliki keinginan untuk mandiri, tidak menggantungkan hidup pada anak dan cucunya, etos kerja mereka juga masih tinggi (Patria \& Mutmainah, 2018).

Berdasarkan hasil penelitian sebagian besar penduduk di Wilayah Wilayah Kelurahan TKK RW 2, Kota Surabaya, menempuh pendidikan terakhir SD sebanyak 29 orang $(85,3 \%)$. Tingkat pendidikan merupakan salah satu faktor yang dapat mempengaruhi self empowerment. Hal ini sesuai dengan (Nuari, 2016) bahwa semakin rendah pendidikan maka self empowerment yang dimiliki lansia juga akan semakin kurang. Kognitif dan intelektual mempengaruhi daya penerimaan individu terhadap stimulus. Lansia diharapkan mampu menerima kondisi perubahannya dan mudah menerima stimulus/stress ekternal dan mengubahnya menjadi pikiran positif sehingga kesiapan untuk pemberdayaan diri baik.

Berdasarkan hasil penelitian sebagian besar responden berjenis kelamin perempuan sebanyak 30 orang $(88,2 \%)$. Hal ini sesuai dengan penelitian oleh (Gunarsih, 2018) yang mengatakan bahwa tingkat pemberdayaan diri lansia perempuan lebih rendah dibandingkan dengan laki-laki.

Berdasarkan hasil penelitian sebagian besar responden tidak bekerja sebanyak 19 orang $(56,0 \%)$. Menurut penelitian bahwa lansia yang bekerja akan memiliki kemampuan untuk memenuhi kebutuhannya dibandingkan dengan lansia yang tidak bekerja. Pekerjaan dapat berdampak positif pada lansia karena dapat memaksimalkan pengalaman bekerjanya untuk memperoleh produktivitas dalam kehidupan sehari-hari, serta dapat mengaselerasikan dirinya secara maksimal pada perannya (Hendrawanto, 2016). Lansia dianggap masih kurang produktif karena pensiun namun disisi lain kebutuhan harian harus terpenuhi khususnya terkait dengan kesehatan dan masalahnya jaminan hari tua atau uang pensiun yang didapat dirasa masih kurang dalam mencukupi kebutuhannya. Sehingga lansia dituntut mencari alternatif pendapatan atau bekerja yang sesuai kemampuan fisik dan pikirnya, tentunya tidaklah mudah dengan adanya keterbatasan lansia (Patria \& Mutmainah, 2018).

Peneliti berpendapat bahwa adanya lansia yang memiliki self empowerment yang buruk menunjukan bahwa berbagai faktor yang dapat mempengaruhi self empowerment pada lansia diantaranya kurangnya ketersediaan informasi dan keterampilan tingkah laku. Kurangnya ketersediaan informasi dapat dilihat dari banyaknya pendidikan SD pada lansia. Tingkat pendidikan lansia berhubungan dengan daya nalar atau kemampuan kognitif lansia dalam menganalisis kondisi kehidupan. Kurangnya keterampilan tingkah laku lansia dapat dilihat dari banyaknya lansia yang tidak bekerja. Pekerjaan berhubungan dengan pemanfaatan 
potensi dalam diri lansia untuk meningkatkan aktivitas. Upaya yang bisa dilakukan untuk meningkatkan self empowerment dengan pemberian pekerjaan melalui pelatihan keterampilan kerajinan pada sektor industri kreatif.

\section{Mengidentifikasi Kualitas hidup pada Lansia}

Hasil penelitian menunjukkan bahwa dari 34 responden sebagian besar memiliki kualitas hidup kurang di Wilayah Wilayah Kelurahan TKK RW 2, Kota Surabaya sebanyak 32 responden $(94,1 \%)$. Kualitas hidup merupakan konsep analisis kemampuan seseorang dalam menjalankan hidup terkait persepsi individu mengenai tujuan, harapan, standar, dan perhatian secara khusus terhadap kehidupan yang dialami dengan dipengaruhi nilai dan budaya pada lingkungan individu berada (Nursalam, 2017). Kualitas hidup dipengaruhi oleh hubungan lansia dengan lingkungan sekitar, kesehatan fisik, usia, pendidikan dan pekerjaan (Salsabila, 2012).

Hasil penelitian sebagian besar lansia berusia 60-74 tahun sebanyak 32 lansia $(94,1 \%)$ berada di Wilayah Kelurahan TKK RW 2, Kota Surabaya memiliki kualitas hidup yang kurang. Hal ini sesuai denga Wikananda (2017), kualitas hidup lansia biasanya cenderung menjadi kurang baik, hal tersebut berhubungan dengan faktor sosio-ekonomi lansia, sebagai contoh akibat berhenti bekerja/pensiun, kehilangan orang terdekat dan ketergantungan kebutuhan hidup serta adanya penurunan kondisi fisik. Perubahan yang terjadi merupakan kendala dalam menentukan kesejahteraan lansia, karena keterbatasan dalam pemenuhan kebutuhan hidup (Andesty \& Syahrul, 2018).

Sebagian besar responden berjenis kelamin perempuan yaitu 30 orang $(88,2 \%)$. Hal ini sejalan dengan studi yang dilakukan oleh Indrayani \& Ronoatmodjo (2018) mengungkapkan bahwa kualitas hidup perempuan lebih rendah daripada laki-laki. Hasil studinya melaporkan bahwa secara signifikan lansia berjenis kelamin perempuan memiliki kepuasan yang kurang dalam beberapa aspek antara lain hubungan personal, kondisi kehidupan kesehatan dukungan keluarga, pelayanan sosial, dan keadaan ekonomi.
Berdasarkan hasil penelitian sebagaian besar penduduk di Wilayah Wilayah Kelurahan TKK RW 2, Kota Surabaya memiliki pendidikan SD sebanyak 29 orang $(85,3 \%)$. Menurut penelitian Ardiani et al. (2014) mengungkapkan tidak adanya pengaruh tingkat pendidikan terhadap kualitas hidup pada lansia dimana tingkat pengetahuan tidak didapatkan dari pendidikan formal saja, namun pengalaman dan informasi dari media lainnya.

Berdasarkan hasil penelitian sebagaian besar responden tidak bekerja sebanyak 19 orang $(56,0 \%)$. Sesuai dengan hasil penelitian Ardiani et al. (2014) terdapat hubungan antara faktor pekerjaan dengan kualitas hidup lansia. Hal tersebut sesuai dengan kondisi kesehatan tidak mendukung lansia untuk bekerja.

Peneliti berpendapat bahwa kualitas hidup lansia menurun karena kemampuan lansia dalam melakukan kegiatan harian terbatas. Dalam hal ini jika kualitas hidup kurang bisa jadi disebabkan oleh kesehatan fisik yang buruk membuat aktivitas mulai menurun dan membuat lansia mengalami perubahan karena adanya penurunan dalam pemenuhan kebutuhan hidup. Upaya dalam meningkatkan kualitas hidup lansia, peran keluarga sangat dibutuhkan dalam memenuhi kebutuhan lansia tersebut. Upaya lain yang dapat dilakukan untuk meningkatkan kualitas hidup lansia yaitu dengan memberikan aktivitas fisik, pengaturan nafas, pengaturan psikologi, cognitive behavioral theraphy, dukungan teman sebaya, konseling, dan intervensi religi.

\section{Mengidentifikasi Hubungan Self Empowerment dengan kualitas Hidup Lansia}

Hasil penelitin pada tabel 4 Menunjukan bahwa sebagian besar responden dengan Self Empowerment memiliki kualitas hidup yang kurang sebanyak 32 (94,1\%) lansia. Hasil uji statistik chi-squere pada variable yaitu $\mathrm{p}=, 000$ artinya ada hubungan yang bermakna antara Self Empowerment dan kualitas hidup lansia.

Self empowerment dengan kualitas hidup kurang pada penelitian ini dikarenakan kurangnya informasi, keterampilan, tingkah laku dan tanggung jawab pribadi sehingga menimbulkan kualitas hidup yang kurang pada lansia. Hal ini sesuai dengan penelitian Adina (2017), lansia yang memiliki self empowerment yang baik maka kualitas hidupnya akan baik 
pula. Berbekal kemandirian, lansia dapat melakukan aktivitas keseharian (ADL) meskipun beberapa aktivitas perlu bantuan. Begitu pula sebaliknya, apabila lansia memiliki pemberdayaan diri rendah maka kualitas hidupnya juga rendah. Sesuai dengan teori yang menyatakan bahwa lansia mengalami penurunan fungsi tubuh akan berdampak pada kemampuan fungsional. Pemberdayaan diri lansia mengalami penurunan mengakibatkan kualitas hidup.

Self empowerment kurang dengan kualitas hidup kurang pada penelitian ini dikarenakan fisik dan psikologis yang menurun, hubungan sosial yang menurun, dan lingkungan tidak mendukung. Hal ini sesuai dengan penelitian Prihati (2017), kualitas hidup lansia kurang jika kondisi fisik, psikologis dan sosial, dan ekonominya kurang. Kesehatan fisik berhubungan dengan pemberdayaan diri lansia dalam kehidupan keseharian. Kondisi fisik kurang mengakibatkan tingkat pemberdayaan diri kurang sehingga lansia akan memiliki kualitas hidup kurang. Lansia mengalami penurunan fisik mengakibatkan ketergantungan sehingga mengalami penurunan pemberdayaan diri dan kualitas hidup.

$$
\text { Peneliti berpendapat lansia }
$$

mengalami persoalan diantaranya rendahnya tingkat pendidikan, susah dalam mengakses fasilitas kesehatan, tidak memiliki jaminan masa tua, dan tidak ada dukungan sosial untuk merawat mereka terutama keluarga. Lansia yang pada akhirnya merasa tidak berdaya dan tidak berguna sehingga pemberdayaan (self empowerment) kurang dalam kehidupan seharihari sehingga mengalami berbagai masalah psikis maupun fisik.

\section{KESIMPULAN}

1. Sebagian besar lansia di Wilayah Wilayah Kelurahan TKK RW 2, Kota Surabaya memiliki Self empowerment yang kurang.

2. Sebagian besar lansia di Wilayah Wilayah Kelurahan TKK RW 2, Kota Surabaya memiliki kualitas hidup yang kurang.

3. Terdapat hubungan antara self empowerment dengan kualitas hidup lansia di Wilayah Wilayah Kelurahan TKK RW 2, Kota Surabaya.

\section{SARAN}

1. Bagi Responden, lansia diharapkan mempunyai motivasi yang tinggi dalam meningkatkan self empowerment (Pemberdayaan diri) dengan cara pemberian pekerjaan melalui pelatihan keterampilan kerajinan pada sektor industri kreatif supaya kualitas hidup lansia menjadi lebih baik.

2. Bagi Tempat Penelitian, diharapkan posyandu lansia yang berada di RW 02 Kelurahan Tanah Kali kedinding Kecamatan Kenjeran Kota Surabaya Provinsi Jawa Timur, mengadakan pelatihan yang dapat meningkatkan self empowerment dan kualitas hidup menjadi lebih baik.

3. Bagi Peneliti Selanjutnya, diharapkan penelitian selanjutnya dapat dijadikan referensi bagi peneliti dan dapat menambahkan faktor-faktor perubahan pada lansia seperti perubahan fisik, perubahan aspek kepribadian, kondisi sosial ekonomi dan aktivitas beribadah.

\section{DAFTAR PUSTAKA}

Adina, A. F. (2017). Hubungan Tingkat Kemandirian Dengan Kualitas Hidup Lansia di Padukuhan Karang Tengah Nogotirti Gamping Sleman Yogyakarta. Universitas Aisyiyah.

Andesty, D., \& Syahrul, F. (2018). Hubungan Interaksi Sosial Dengan Kualitas Hidup Lansia Di Unit Pelayanan Terpadu (Uptd) Griya Werdha Kota Surabaya Tahun 2017. The Indonesian Journal of Public Health, 13(2), 169-180. https://doi.org/10.20473/ijph.v13i2.2018.1 71-182

Ardiani, H., Lismayanti, L., \& Rosnawaty, R. (2014). Faktor-faktor Yang Berhubungan Dengan Kualitas Hidup Lansia Di Kelurahan Mugasari Kecamatan Tamansari Kota Tasikmalaya Tahun 2014. 42-50.

Badan Pusat Statistik. (2013). Proyeksi Penduduk Indonesia Population Projection 2010-2035. In Bulletin of Experimental Biology and Medicine (Vol. 90). Badan Pusat Statistik. https://doi.org/10.1007/BF00830441

Fajriana. (2017). Pengaruh Empowerment, Self Efficacy , Dan Budaya Organisasi Terhadap Kinerja Karyawan (Studi pada 
Karyawan PT. Holcim Indonesia Tbk di Cilacap). Muhammadiyah Purworejo.

Gallo, J. J. (2008). Pengkajian Status Mental (edisi 2). EGC.

Gunarsih, A. E. (2018). Pengaruh ACC (Acceptance And Commtment Care) Terhadap Penerimaan Diri Lanjut Usia Yang Hidup Di Panti Werdha Surabaya. iuversitas Airlangga Surabaya.

Hendrawanto, T. (2016). Pemberdayaan dan Pengembangan Potensi Lansia menghadapi Masa Pensiun. PKS, 15(4), 349-356.

Indrayani, \& Ronoatmodjo, S. (2018). Faktorfaktor Yang Berhubungan Dengan Kualitas Hidup Lansia Di Desa Cipasung Kabupaten Kuningan. Kesehatan Reproduksi, 9(1), 69-78. https://doi.org/10.22435/kespro.v9i1.892.6 9-78

Nainggolan, T. (2014). Pemberdayaan Diri Lanjut Usia Peserta Program Asistensi Sosial Lanjut Usia Terlantar Di Kabupaten Bangli. Sosio Konsepsia, 3, 144.

Nuari, N. afrian. (2016). Pengembangan model peningkatan pemberdayaan diri dan kualitas hidup pasien diabetes mellitus tipe 2. Ners Lentera, 4(2), 152-165.

Nursalam. (2017). Metode Penelitian Ilmu Keperawatan. Salemba Medika.

Patria, A. S., \& Mutmainah, S. (2018). Model Pemberdayaan Kelompok Lanjut Usia Wanita Melalui Industri Kreatif. E-Dimas: Jurnal Pengabdian Kepada Masyarakat, 9(1), 15-27. https://doi.org/10.26877/edimas.v9i1.2019

Prihati, pradhitya A. (2017). Hubungan Tingkat Kemandirian Activity Daily Living (ADL) Dengan Kualitas Hidup Lansia Di Kleurahan Karang Asem Kecematan Lawean Surakarta. Universitas Muhammadiyah Surakarta.

Rahayu, M. F. (2013). Hubungan Pemberdayaan Diri Dengan Kualitas Hidup Pada Pasien Diabetes Mwlitus Tipe II Di Poli Penyakit dalam RS. Tingkat III Baladhika Husada Jember. Univaeritas Jember.

Rohanah, \& Suyatini. (2018). Pengaruh Pemberdayaan Keluarga Terhadap Kualitas Hidup Lansia di Kelurahan Karangsari Tangerang Tahun 2017. Jurnal Medikes, 5(November), 168-173.

Rohmah, A. I. N., Purwaningsih, \& Bariyah, K.
(2012). Quality of Life Elderly. Jurnal Keperawatan, 3(2), 120-132.

Salsabila, S. M. (2012). Kualitas Hidup Pasien Epilepsi (Studi Kasus Pasien Epilepsi Dewasa Awal di Yogyakarta). Universitas Islam Negeri Sunan Kalijaga Yogyakarta.

WHO. (2013). World Health Statistics 2013 (2013th ed.).

Wikananda, G. (2017). Hubungan Kualitas Hidup dan Faktor Resiko pada Usia Lanjut di Wilayah Kerja Puskesmas Tampaksiring 1 Kabupaten Gianyar Bali 2015. Intisari Sains Medis, 8(1), 41-49. https://doi.org/10.15562/ism.v8i1.112 